\title{
Partial Purification and Some Properties of Polyphenoloxidases from Sago Palm
}

\author{
Akiko Oxamoto, Hiroshi Imagawa, Yuji Arai and Tetsuo Ozawa \\ Institute of Applied Biochemistry, University of Tsukuba, \\ Tsukuba-shi, Ibaraki 305, Japan
}

Received March 8, 1988

\begin{abstract}
Two polyphenoloxidases (PPO I and PPO III, EC 1.10.3.1) were extracted and partially purified from sago palm pith by hydroxylapatite chromatography, DEAE-cellulose chromatography and gel filtration. Both purified isozymes gave a single activity band on polyacrylamide gel electrophoresis. The molecular weights of both enzymes were estimated to be 40,000 . They had the same pH optima of 6.5 but different temperature optima, $35^{\circ} \mathrm{C}$ for PPO I and $45^{\circ} \mathrm{C}$ for PPO III. PPO I was stable at neutral to alkaline $\mathrm{pH}$ and PPO III at acidic $\mathrm{pH}$. PPO III was somewhat more stable than PPO I when incubated at various temperatures for $15 \mathrm{~min}$. PPO I and PPO III oxidized well DL-epicatechin and D-catechin, respectively. Both enzymes were strongly inhibited by $\mathrm{KCN}$, $\mathrm{Na}$-diethyldithiocarbamate and $\mathrm{NaHSO}_{3}$.
\end{abstract}

Sago palm (Metroxylon sagus, Rottb.) is distributed in marshy areas in Southeast Asia. ${ }^{1)}$ This plant stores a large amount of starch in its stem, the starch productivity of sago palm per ha per year being higher than that of wheat or corn. ${ }^{2)}$ Besides, this plant can grow on tropical acidic marshy ground, that cannot be utilized as farmland, and is saltresistant to a certain extent. Due to these facts, sago palm is considered to be a prospective carbohydrate source.

However, sago starch is not fully exploited because of its low quality. ${ }^{3)}$ One of the most important factors which lower its quality is its color, which is due to the browning of the pith. When the pith of sago palm is chopped to extract the starch, it displays a strong brown color, starch granules deteriorate and a brownish starch is eventually produced. Since brownish starch is not suitable for industrial or commercial use, sago starch is not fully utilized at present.

To prevent the browning and to improve the quality of sago starch, the mechanism of browning of the sago pith was studied. The browning was considered to be caused by the oxidation of polyphenols by oxidases con- tained in the pith. D-Catechin and DLepicatechin were isolated from the sago pith as the compounds which cause the browning. ${ }^{+)}$ The present paper deals with the partial purification and characterization of polyphenoloxidases contained in sago palm pith.

\section{MATERIALS AND METHODS}

Material. The pith of sago palm, Metroxylon sagus, Rottb. was collected in Sibu, Sarawak, Malaysia, within a few days after cutting.

Chemicals. 2-Nitro-5-thiobenzoic acid anion (TNB) was prepared from 5,5'-dithiobis(2-nitrobenzoic acid) as reported by Esterbauer et al. ${ }^{5\}} \mathrm{D}$-Catechin was isolated from gambir. L-Epicatechin and L-epigallocatechin were isolated from tea. D-Epicatechin was prepared from Dcatechin by the method of Freudenberg and Purmann ${ }^{6}$ with a slight modification. DL-Epicatechin was isolated from sago palm pith. ${ }^{+1}$ All other chemicals were of analytical grade.

Enzyme extraction and 1st hydroxylapatite column chromatography. The fresh pith was cut into small pieces, crushed with a Waring Blender in cold acetone and then filtered on a Büchner funnel. The residue was homogenized in $80 \%$ acetone with a Polytron and then filtered. After washing with $80 \%$ acetone, the residue was lyophilized and stored at $-20^{\circ} \mathrm{C}$. The powder $(50 \mathrm{~g})$ thus 
prepared was suspended in $400 \mathrm{ml}$ of $0.01 \mathrm{M}$ sodium phosphate buffer, $\mathrm{pH} 6.8$, stirred for $1 \mathrm{hr}$ at $4^{\circ} \mathrm{C}$ and then filtered through 3 layers of cheese cloth. The filtrate was centrifuged at $28,000 \times g$ for $20 \mathrm{~min}$ and the supernatant was concentrated by ultrafiltration with a UP-20 membrane (Toyo Roshi Co.). The concentrate was dialysed against $0.01 \mathrm{M}$ sodium phosphate buffer, $\mathrm{pH} 6.8$, overnight and then cleared by centrifugation at $35,000 \times g$ for $15 \mathrm{~min}$. The supernatant was applied to a hydroxylapatite column (Biogel HTP, $1.6 \times 15 \mathrm{~cm}$ ) preequilibrated with the above buffer. The column was washed with the same buffer and eluted with a $300 \mathrm{ml}$ of a linear gradient of phosphate $(0.01 \sim 0.4 \mathrm{M})$. Fractions $(4 \mathrm{ml})$ were collected and assayed for polyphenoloxidase (PPO) and peroxidase (POD) activity (Fig. 1).

2nd hydroxylapatite column chromatography. The PPO III fractions (tubes No. 125 140 from the Ist hydroxylapatite column) were pooled, the buffer was exchanged for 0.01 M sodium phosphate buffer, $\mathrm{pH} 6.8$, using an Amicon PM-10 ultrafiltration membrane, and then the enzyme was applied to a column $(1.0 \times 15 \mathrm{~cm})$ preequilibrated with $0.01 \mathrm{M}$ sodium phosphate buffer, $\mathrm{pH}$ 6.8. The column was washed and eluted with a $180 \mathrm{ml}$ of a linear gradient of phosphate $(0.01 \sim 0.4 \mathrm{M})$. Fractions $(1.3 \mathrm{ml})$ were collected and assayed for PPO and POD activity.

Gel filtration. The fractions which showed PPO III activity after the 2nd hydroxylapatite column chromatography were concentrated to $0.3 \sim 0.5 \mathrm{ml}$ with an Amicon PM-10, and then applied to a Sephadex G-100 column $(1.0 \times 80 \mathrm{~cm})$ preequilibrated with $0.025 \mathrm{M}$ phosphate buffer, $\mathrm{pH} 6.8$, and eluted with the same buffer. Fractions $(1.5 \mathrm{ml})$ were collected and assayed for PPO and POD activity. Those that showed PPO activity were pooled and concentrated.

DEAE-Cellulose column chromatography. PPO I (tubes No. $101 \sim 114$, from the 1 st hydroxylapatite column) was equilibrated with $0.01 \mathrm{M}$ sodium phosphate buffer, $\mathrm{pH} 6.0$, using an Amicon PM-10, and then applied to a DE-52 (Whatman) column $(1.0 \times 15 \mathrm{~cm})$ preequilibrated with the above buffer. The column was eluted with a $180 \mathrm{ml}$ of a linear gradient of $\mathrm{NaCl}(0 \sim 0.5 \mathrm{M}$ in $0.01 \mathrm{M}$ sodium phosphate buffer, $\mathrm{pH} 6.0$ ). Fractions $(1.5 \mathrm{ml})$ were collected and assayed for PPO and POD activity.

The fractions which showed PPO I activity were collected and further purified by gel filtration as in the case of PPO III.

Assays of PPO activity. PPO activity was assayed by three methods.

1) TNB Method. The PPO activity was assayed by the method of Esterbauer et al. ${ }^{5}$ with a slight modification. Unless otherwise specified, the reaction mixture contained $0.975 \mathrm{ml}$ of $10 \mathrm{mM} \mathrm{D}$-catechin in $0.1 \mathrm{M}$ sodium phosphate buffer, $\mathrm{pH} 6.0,5 \mu \mathrm{l}$ of $9.6 \mathrm{~mm}$ TNB solution and $25 \mu \mathrm{l}$ of the enzyme solution. A mixture of D-catechin and the TNB solution was preincubated at $30^{\circ} \mathrm{C}$ in a micro-cuvette and then the reaction was initiated by the addition of the enzyme. The decrease in absorbance was followed at $412 \mathrm{~nm}$ with a spectrophotometer (Hitachi model 200-10, equipped with a recorder and a cell holder maintained in a thermostat) for $1 \mathrm{~min}$. One unit of enzyme activity was defined as the amount of enzyme which induced a change of $0.01 / \mathrm{min}$ in absorbance.

2) Direct colorimetric method. This method was used for examination of the effects of metal ions. The reaction mixture consisted of $1 \mathrm{ml}$ of $5 \mathrm{~mm}$ D-catechin solution in $0.1 \mathrm{M}$ sodium phosphate buffer, $\mathrm{pH} 6.0$, containing various concentrations of metals and $25 \mu \mathrm{l}$ of the enzyme solution. The assay mixture was preincubated at $30^{\circ} \mathrm{C}$ in a microcuvette and then the reaction was initiated by the addition of the enzyme. The increase in absorbance was followed at $420 \mathrm{~nm}$ with a spectrophotometer for $2 \mathrm{~min}$.

3) $\mathrm{O}_{2}$ Electrode method. This method was used for determination of the substrate specificity. The enzyme activity was assayed at $30^{\circ} \mathrm{C}$ using a Garvani-type oxygen electrode (DO meter model MD-1000; Ijima Products $\mathrm{Mfg}$.). The reaction mixture consisted of $2 \mathrm{ml}$ of $5 \mathrm{mM}$ substrate solution in $0.1 \mathrm{~m}$ sodium phosphate buffer, $\mathrm{pH}$ 6.0 , and $30 \mu \mathrm{l}$ of the enzyme solution. The reaction was initiated by the addition of the enzyme and the rate of the reaction was calculated from the linear part of the trace of $\mathrm{O}_{2}$ consumption.

Assay of POD activity. The activity of POD was assayed by the method of Tomiyama and Stahmann." The reaction mixture consisted of $0.78 \mathrm{ml}$ of $0.1 \mathrm{M}$ sodium phosphate buffer, $\mathrm{pH} 6.0,0.17 \mathrm{ml}$ of $20 \mathrm{~mm}$ guaiacol, $30 \mu \mathrm{l}$ of $30 \mathrm{mM} \mathrm{H} \mathrm{H}_{2} \mathrm{O}_{2}$ and $50 \mu \mathrm{l}$ of the enzyme solution. The substrate solution was preincubated at $30^{\circ} \mathrm{C}$ in a microcuvette and the reaction was initiated by the addition of the enzyme, and the increase in the absorbance at $420 \mathrm{~nm}$ was measured in the same way as described above. One unit of activity was defined as the amount of enzyme which induced a change of $0.01 / \mathrm{min}$ in absorbance.

Protein determination. The protein contents of the enzyme preparations were determined by the method of Bradford $^{81}$ using a Bio-Rad Protein Assay Kit with tyrosinase (Sigma) as the standard protein.

Molecular weight estimation. The molecular weights of the enzymes were determined by Sephadex G-100 column $(1.0 \times 80 \mathrm{~cm})$ chromatography. Cytochrome $c(12,500)$ chymotrypsinogen $A(25,000)$, ovalbumin $(45,000)$ and bovine serum albumin $(68,000)$ were used as molecular weight markers.

Disc-PAGE. This procedure was performed essentially as described by Davis ${ }^{9)}$ using tubes of $0.5 \mathrm{~cm}$ i.d. filled to $6 \mathrm{~cm}$ with $7.5 \%$ polyacrylamide. The gels were run at $1 \mathrm{~mA} /$ tube with BPB as a marker. The gels were stained for 
PPO activity by immersion in a $10 \mathrm{~mm}$ D-catechin solution in $0.1 \mathrm{M}$ sodium phosphate buffer, $\mathrm{pH} 6.0$, and then incubated at $30^{\circ} \mathrm{C}$. For the POD activity, the gels were stained according to the method of Brewbaker et al. ${ }^{10}$ with $o$-dianisidine as the substrate.

\section{RESULTS}

\section{Enzymes related to catechin oxidation}

The crude extract from the sago palm pith was subjected to polyacrylamide gel electrophoresis (PAGE), and the gels were stained with a solution of D-catechin, which is one of the compounds responsible for the browning of sago starch. At least $4 \sim 5$ bands showing oxidase activity were detected. Among them, the bands with $R m$ s of 0.3 and 0.6 were identified as PPOs and those with $R m$ s of 0.1 , 0.3 and 0.4 as PODs, although the band with an $R m$ of 0.3 overlapped the corresponding PPO one. Based on these results it was considered that PPOs and PODs were responsible for the browning of sago starch.

\section{Enzyme extraction}

The oxidases were extracted from the acetone powder with $0.01 \mathrm{M}$ sodium phosphate buffer, $\mathrm{pH} 6.8$. Almost $80 \%$ of the total oxidase activity was found in the extract after three extractions with the same buffer.

Extraction of the enzymes with $0.01 \mathrm{M}$ sodium phosphate buffer, $\mathrm{pH} 6.8$, containing $1 \%$ detergents was also performed to improve the extraction efficiency. Triton X-100, ${ }^{11)}$ Tween $80^{12)}$ and $\mathrm{HCO}-60,{ }^{13)}$ which were reported to be effective detergents for PPO extraction from plants, were tested, but none of them improved the solubilization of PPOs in the sago palm pith.

\section{Enzyme purification}

Hydroxylapatite column chromatography. As shown in Fig. 1, the elution pattern revealed three peaks of PPO that depended on the phosphate concentration (PPO I, PPO II and PPO III, in order of elution). Most of the POD was not bound to the column, only one isozyme, which showed an $R m$ of 0.1 on PAGE, being adsorbed. Among these oxidases, PPO I and PPO III were further purified and characterized.

The crude extract of the acetone powder contained a large amount of viscous substances. The hydroxylapatite column was effective in separating the viscous substances from PPOs. Besides, the color of the crude extract, light yellow or light orange, was also removed.

Further purification of PPO I. The PPO I fractions obtained on hydroxylapatite column chromatography were pooled and then applied to a DEAE-cellulose column. PPO I and POD were separated completely on linear gradient

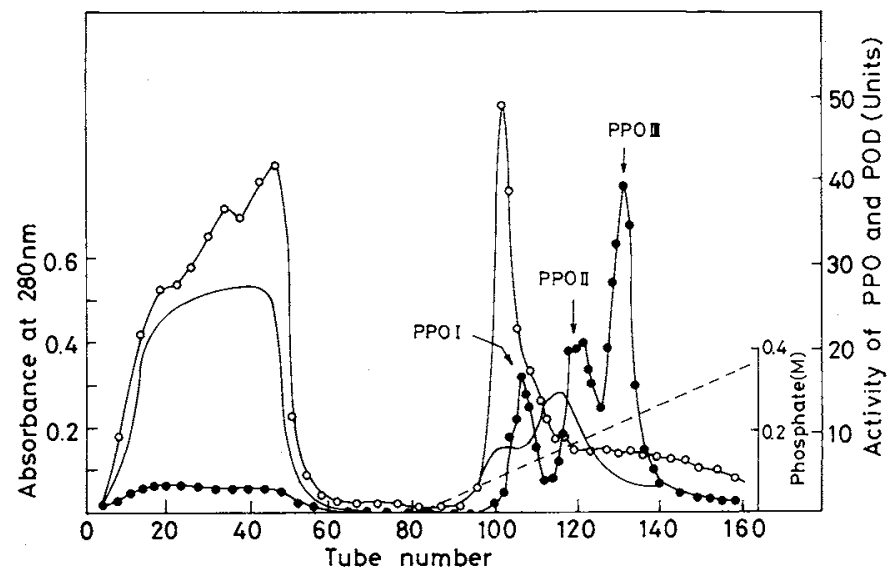

FIG. 1. Hydroxylapatite Column Chromatography of the Crude Extract. 
elution of $\mathrm{NaCl}$ and then PPO I was chromatographed on a Sephadex G-100 column. Most of the contaminating proteins were removed from PPO I by the gel filtration. The purified PPO I gave a single enzyme-activity band on PAGE $(R m 0.58)$, there being a $5.7 \%$ recovery of the enzyme activity with a purification of 11.8-fold (Table Ia).

Further purification of PPO III. The PPO III fractions from the 1st hydroxylapatite column were pooled and then rechromatographed on a hydroxylapatite column with a lower gradient than that used for the 1 st column. The peak fractions of this eluate were pooled and then applied to a Sephadex G-100 column. Most proteins contaminating PPO III were removed by the gel filtration. The enzyme was homogeneous, with the activity being stained after PAGE $(R m 0.3)$ and there was a $5.3 \%$ recovery

\section{Table I. Purification of PPO I AND} PPO III FROM $M$. sagus

a: Purification of PPO I

\begin{tabular}{lccc} 
Total & Total & Specific & Yield \\
protein & activity & $\begin{array}{c}\text { activity } \\
\text { (units } / \mu \mathrm{g}\end{array}$ & $(\%)$ \\
protein $)$ & $\left(10^{3} \mu \mathrm{g}\right)\left(10^{3}\right.$ units & \\
\hline
\end{tabular}

\begin{tabular}{lrrrr}
\hline $\begin{array}{l}\text { Buffer extraction } \\
\text { of acetone }\end{array}$ & & & & \\
$\quad$ powder & 26.3 & 58.9 & 2.2 & 100.0 \\
Hydroxylapatite & 3.2 & 15.0 & 4.6 & 25.5 \\
DEAE-Cellulose & 0.67 & 9.3 & 13.9 & 15.8 \\
Sephadex G-100 & 0.13 & 3.4 & 26.1 & 5.8 \\
\hline
\end{tabular}

b: Purification of PPO III

\begin{tabular}{|c|c|c|c|c|}
\hline Step & $\begin{array}{l}\text { Total } \\
\text { protein } \\
\left(10^{3} \mu \mathrm{g}\right)\end{array}$ & $\begin{array}{c}\text { Total } \\
\text { activity } \\
\left(10^{3} \text { units }\right)\end{array}$ & $\begin{array}{c}\text { Specific } \\
\text { activity } \\
\text { (units } / \mu \mathrm{g} \\
\text { protein) }\end{array}$ & $\begin{array}{l}\text { Yield } \\
(\%)\end{array}$ \\
\hline $\begin{array}{c}\text { Buffer extraction } \\
\text { of acetone }\end{array}$ & 365 & 74.4 & 20 & 1000 \\
\hline $\begin{array}{l}\text { Hydroxylapatite } \\
\text { (1st) }\end{array}$ & 0.36 & 23.4 & 65.0 & 31.5 \\
\hline $\begin{array}{l}\text { Hydroxylapatite } \\
\text { (2nd) } \\
\text { Sephadex G-100 }\end{array}$ & $\begin{array}{l}0.05 \\
0.013\end{array}$ & $\begin{array}{l}9.9 \\
3.9\end{array}$ & $\begin{array}{l}198.0 \\
300.0\end{array}$ & $\begin{array}{r}13.3 \\
5.2\end{array}$ \\
\hline
\end{tabular}

The data in $a$ and $b$ were obtained for different batches. of the activity with a purification of 150 -fold (Table Ib).

\section{Molecular weight}

The molecular weights of both PPO I and PPO III were estimated to be 40,000 by gel filtration on the Sephadex G-100 column.

\section{Effect of $p H$}

The optimum $\mathrm{pH}$ for both PPO I and PPO III was 6.5 , and the activity was negligible below pH 4 and above 9 (Fig. 2a).

Figure $2 b$ shows the $\mathrm{pH}$ stabilities of PPO I and PPO III. Both enzymes were exposed to various $\mathrm{pHs}$ for $18 \mathrm{hr}$ at $4^{\circ} \mathrm{C}$ and then the remaining activities were assayed at the stan-

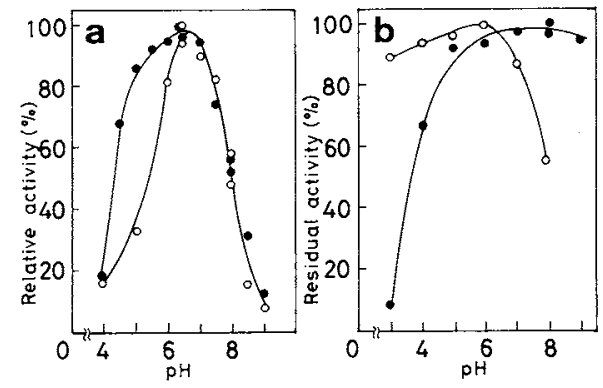

FIG. 2. Effect of $\mathrm{pH}$.

(a) $\mathrm{pH}$-Activity curve, the assay temperature was $30^{\circ} \mathrm{C}$. Buffer: pH $4 \sim 6.5$, McIlvaine buffer; $\mathrm{pH} 6.5 \sim 8.0$, phosphate buffer; pH $8.0 \sim 9.0$, Tris- $\mathrm{HCl}$ buffer.

(b) pH-Stability curve, the remaining activity was assayed at $30^{\circ} \mathrm{C}$ and $\mathrm{pH} 6.0$. Buffer: $\mathrm{pH} 3.0 \sim 8.0$, McIlvaine buffer; pH $8.0 \sim 9.0$, Tris- $\mathrm{HCl}$ buffer.

-, PPO I; O-O, PPO III.

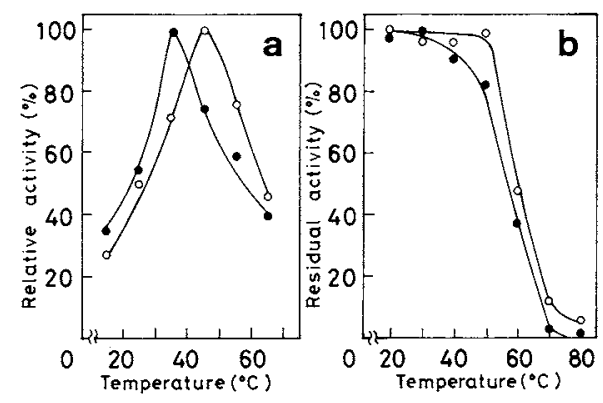

FIG. 3. Effect of Temperature.

(a) Temperature-activity curve, the assay $\mathrm{pH}$ was 6.0 .

(b) Temperature stability curve, the remaining activity was assayed at $30^{\circ} \mathrm{C}$ and $\mathrm{pH} 6.0$.

Symbols, see Fig. 2. 
dard $\mathrm{pH}$. PPO I was relatively stable above $\mathrm{pH}$ 5 and even at $\mathrm{pH} 10$ about $90 \%$ of the initial activity remained. PPO III was relatively stable at an acidic $\mathrm{pH}$ and nearly $90 \%$ of the initial activity remained at $\mathrm{pH} 3$.

\section{Effect of temperature}

The optimum reaction temperature for $\mathrm{PPO}$ I was found to be $35^{\circ} \mathrm{C}$ and that for PPO III to be $45^{\circ} \mathrm{C}$ (Fig. 3a).

Figure $3 \mathrm{~b}$ shows the temperature stabilities of PPO I and PPO III. After incubation for $15 \mathrm{~min}$ at various temperatures, the remaining activities were assayed at the standard temperature. PPO I hardly lost any activity at $30^{\circ} \mathrm{C}$. Above $40^{\circ} \mathrm{C}$, PPO I was inactivated gradually and no activity remained at $80^{\circ} \mathrm{C}$. PPO III was not inactivated on incubation for $15 \mathrm{~min}$ at $40^{\circ} \mathrm{C}$ but gradually lost its activity at above $50^{\circ} \mathrm{C}$.

\section{Effects of inhibitors}

Table II shows the effects of various inhibitors on the activities of PPO I and PPO III. The two isozymes showed similar behaviors. $\mathrm{Na}-$ Diethyldithiocarbamate (Na-DIECA), thiourea and $\mathrm{KCN}$, which affect copper enzymes, ${ }^{14)}$ inhibited the activities of both PPO I and PPO III. Among them, $\mathrm{KCN}$ and $\mathrm{Na}-$

TABLE II. INHIBITORS OF PPO I AND PPO III FROM $M$. sagus

\begin{tabular}{lcc}
\hline & \multicolumn{2}{c}{$\begin{array}{c}\text { Concentration required for } \\
50 \% \text { inhibition }\left(10^{-3} \mathrm{M}\right)\end{array}$} \\
\cline { 2 - 3 } Inhibitor & PPO I & PPO III \\
\hline $\mathrm{NaN}_{3}$ & 8.7 & 7.3 \\
$\mathrm{Thiourea}_{\text {Benzoic acid }}$ & 4.6 & 3.4 \\
$\mathrm{Na}_{2} \mathrm{SO}_{3}$ & 3.8 & 2.9 \\
$\mathrm{NaHSO}_{3}$ & 2.7 & 2.5 \\
$\mathrm{Na}-\mathrm{DIECA}$ & 2.0 & 1.8 \\
$\mathrm{KCN}$ & 0.5 & 0.19 \\
\end{tabular}

The reaction mixture $(1 \mathrm{ml})$ contained $0.1 \mathrm{M}$ sodium phosphate buffer, pH $6.0,5.0 \times 10^{-5} \mathrm{M}$ TNB, $10 \mathrm{~mm} \mathrm{D}-$ catechin, various amounts of inhibitors and enzymes. The reaction was initiated by the addition of the enzymes (20 units for D-catechin).
DIECA were the most potent inhibitors of both enzymes. Reducing agents such as $\mathrm{Na}_{2} \mathrm{SO}_{3}$ and $\mathrm{NaHSO}_{3}$ also inhibited the activities of both enzymes. EDTA and $\mathrm{NaCl}$ hardly inhibited the activity of either enzyme and more than $80 \%$ of the initial activity remained even at a concentration of $10 \mathrm{~mm}$ of the reagents.

Table III. Effects of Metal Ions

\begin{tabular}{|c|c|c|c|}
\hline \multirow{2}{*}{ Metal ion } & \multirow{2}{*}{$\begin{array}{l}\text { Concentration } \\
(\mathrm{mM})\end{array}$} & \multicolumn{2}{|c|}{ Relative activity $(\%)$} \\
\hline & & PPO I & PPO III \\
\hline None & & 100 & 100 \\
\hline \multirow[t]{3}{*}{$\mathrm{CuSO}_{4}$} & 0.01 & 153 & 137 \\
\hline & 0.1 & 352 & 291 \\
\hline & 0.9 & - & - \\
\hline \multirow[t]{3}{*}{$\mathrm{ZnSO}_{4}$} & 0.01 & 115 & 103 \\
\hline & 0.1 & 154 & 137 \\
\hline & 0.9 & 210 & 250 \\
\hline \multirow[t]{3}{*}{$\mathrm{MnCl}_{2}$} & 0.01 & 98 & - \\
\hline & 0.1 & 115 & 106 \\
\hline & 0.9 & 140 & 116 \\
\hline \multirow[t]{3}{*}{$\mathrm{CoCl}_{2}$} & 0.01 & 98 & - \\
\hline & 0.1 & 144 & 100 \\
\hline & 0.9 & 183 & 156 \\
\hline \multirow[t]{3}{*}{$\mathrm{NiCl}_{2}$} & 0.01 & 98 & $一$ \\
\hline & 0.1 & 115 & 97 \\
\hline & 0.9 & 138 & 141 \\
\hline
\end{tabular}

The reaction between metal ions and D-catechin was almost negligible at these concentrations.

Table IV. Substrate Specificities of the PPOs

\begin{tabular}{lrr}
\hline & \multicolumn{2}{c}{ Relative activity $(\%)$} \\
\cline { 2 - 3 } Substrate & PPO I & PPO III \\
\hline Catechol & 130.0 & 70.0 \\
D-Catechin & 100.0 & 100.0 \\
L-Epicatechin & 155.0 & 72.0 \\
D-Epicatechin & 82.5 & 48.0 \\
DL-Epicatechin & 175.0 & 60.0 \\
4-Methyl catechol & 925.0 & 168.0 \\
Chlorogenic acid & 350.0 & 92.0 \\
Caffeic acid & 75.0 & 28.0 \\
Pyrogallol & 70.0 & 48.0 \\
L-Epigallocatechin & 17.5 & 0.0 \\
Gallic acid & 17.5 & 14.0 \\
Tyrosine & 0.0 & 0.0 \\
p-Cresol & 30.0 & 16.0 \\
Resorcinol & 7.5 & 6.0 \\
Quinol & 15.0 & 10.0 \\
\hline
\end{tabular}


TABle V. Km and $V_{\max }$ Values of the PPOS TOWARD CATECHINS

\begin{tabular}{lccccc}
\cline { 3 - 5 } Substrate & \multicolumn{2}{c}{ PPO I } & & \multicolumn{2}{c}{ PPO III } \\
\cline { 2 - 3 } \cline { 5 - 6 } & $K m$ & $\begin{array}{c}V_{\max } \\
\left(\Delta A_{412} /\right. \\
\text { min })\end{array}$ & & $K m$ & $\begin{array}{c}V_{\max } \\
\left(\Delta A_{412} /\right. \\
\min )\end{array}$ \\
\hline D-Catechin & 5.00 & 30.3 & & 3.00 & 29.4 \\
L-Epicatechin & 3.85 & 43.4 & & 11.10 & 47.6 \\
D-Epicatechin & 6.67 & 18.2 & & 3.22 & 10.7 \\
DL-Epicatechin & 3.03 & 38.6 & & 5.26 & 19.2 \\
\hline
\end{tabular}

The enzyme activity was assayed by the TNB method. The reaction was initiated by adding 20 units (for $\mathrm{D}^{-}$ catechin) of the enzymes.

\section{Effects of metal ions}

PPO I and PPO III also showed quite similar behaviors for metal ions (Table III). $\mathrm{Cu}^{2+}, \mathrm{Zn}^{2+}, \mathrm{Mn}^{2+}, \mathrm{Co}^{2+}$ and $\mathrm{Ni}^{2+}$ enhanced the oxidizing reaction. Among them, $\mathrm{Cu}^{2+}$ and $\mathrm{Zn}^{2+}$ showed remarkable activation while $\mathrm{Mn}^{2+}, \mathrm{Co}^{2+}$ and $\mathrm{Ni}^{2+}$ had hardly any effect below $0.1 \mathrm{~mm}$.

\section{Substrate specificity}

Table IV shows the substrate specificities of PPO I and PPO III. Both enzymes hardly oxidized monohydroxy or $m$ - or $p$-dihydroxy phenols. They oxidized trihydroxy phenols to some degree.

PPO I and PPO III oxidized $o$-dihydroxy phenols well, but their specificities for $o$ dihydroxy phenols were different. PPO I oxidized well 4-methyl catechol, chlorogenic acid, L-epicatechin and DL-epicatechin, while PPO III rapidly oxidized 4-methyl catechol, chlorogenic acid and D-catechin.

The activities of both PPO I and PPO III were inhibited by an excess of D-catechin and the Michaelis-Menten's formula could not be applied for either enzyme at more than $15 \mathrm{~mm}$.

\section{DISCUSSION}

Sago palm pith is a white, soft tissue containing a large amount of starch. After cutting, the color of the pith changes to dark-brown even when stored at a low temperature. An acetone powder was prepared to preserve the material for the enzyme study. Loss of the oxidase activity of the sago pith was minimal with this process. In addition, it was shown that the activities of the enzymes did not change on preparation of the acetone powder, as judged when the zymographic pattern of the extract from the acetone powder and that of the extract from the raw pith were compared on PAGE. The acetone powder could be stored at $-20^{\circ} \mathrm{C}$ for a long period with little loss of the activity, as reported by Harel et al. ${ }^{15)}$

Since most of the oxidases in the sago palm pith were extracted only with $0.01 \mathrm{~m}$ sodium phosphate buffer, these enzymes were considered to be water-soluble enzymes, like those in peach ${ }^{16)}$ and pear, ${ }^{17,18)}$ and not enzymes of the membrane-bound type, like those in tea. ${ }^{6)}$

On PAGE it was found that PODs as well as PPOs oxidized D-catechin, suggesting that PODs oxidized D-catechin to some extent without $\mathrm{H}_{2} \mathrm{O}_{2}$. However, as shown in Fig. 1, the oxidase activity for D-catechin of PODs was low, most of the activity being assigned to PPOs. Therefore, it was considered that the enzymes directly responsible for the catechin oxidation and browning were PPOs, and not PODs.

PPO II exhibited polyphenoloxidase activity when it was assayed by the methods described under Materials and Methods, but the activity increased during storage at $4^{\circ} \mathrm{C}$ suggesting that it may be a precursor of PPO, as reported by Söderhall et al. ${ }^{19}$ and Ichishima et $a l^{20)}$ Detailed studies on PPO II are currently in progress.

It has been reported that the molecular weights of polyphenoloxidases vary widely from 144,000 to 5300 , depending on the source. ${ }^{14)}$ The molecular weights of PPO I and PPO III showed a similar value of 40,000 , as in the case of the PPOs from Japanease pear, ${ }^{18}$ broad bean ${ }^{21)}$ and potato. ${ }^{16)}$

PPO I and PPO III exhibited different properties, for example, PPO I was stable at neutral to alkaline pHs while PPO III was stable at acidic $\mathrm{pH}$. PPO III was more resistant to heat denaturation than PPO I and showed a 
higher optimum temperature. Among these properties, the difference in the substrate specificities was remarkable.

It is interesting to note that the enzymes reacted differently with four isomers of catechins, D-catechin, L-epicatechin, D-epicatechin and DL-epicatechin. As mentioned previously, D-catechin and DL-epicatechin were isolated from sago palm as substrates for PPOs. PPO I oxidized DL-epicatechin better than D-catechin, while PPO III oxidized Dcatechin more rapidly than DL-epicatechin. Table $\mathrm{V}$ shows the $K m$ and $V_{\max }$ values of PPO I and PPO III, which confirm the above results. It is considered from these facts that these two isozymes may share an oxidative role as to the substrates.

DL-Epicatechin is a mixture of D-epicatechin and L-epicatechin, in the ratio of $1: 1$. It was observed that PPO I oxidized DL-epicatechin and L-epicatechin in almost equal amounts, although D-epicatechin alone was not appreciably oxidized (Table IV). The detailed mechanism underlying the oxidation is not clear, but the possibility that D-epicatechin and L-epicatechin are oxidized synergistically is considered.

To prevent the browning of sago palm pith and sago starch, a study on the inhibitors is important. PPO I and PPO III were inhibited by the general inhibitors of PPOs, particularly $\mathrm{KCN}$ and Na-DIECA. This indicates that both isozymes have copper molecules in their active sites, as do PPOs from other plants, ${ }^{14}$ although the concentrations of the reagents required for the inhibition of PPO I and PPO III were higher than those for the inhibition of other plant PPOs. ${ }^{23,24)}$

PPO I and PPO III were also inhibited by reducing agents. These reagents may be the most effective for practical use due to their lack of toxicity. $\mathrm{NaHSO}_{3}$ inhibits both PPO I and PPO III strongly and the use of this reagent in the production process for sago starch may prevent the browning of sago pith and starch.

It was found that metal ions enhanced the oxidation. In the present case, water from a river was used to extract starch from the sago pith. The water of a tropical river contains a considerable amount of metal ions, which may increase the browning of sago pith and starch. Therefore, the use of clearer water for the process was also suggested for prevention of the browning.

Acknowledgments. We wish to thank Ajinomoto (Malaysia) Bhd. and Sarawak Chemical Industries Sdn. Bhd. for the supply of sago palm pith.

\section{REFERENCES}

1) G. Nishikawa, K. Oda and H. Suganuma, Japan. $J$. Trop. Agr., 23, 123 (1979).

2) I. Nagato and H. Shimoda, Japan. J. Trop. Agr., 23, 160 (1979).

3) T. Yatugi, "Proceedings of the Third International Sago Symposium," ed. by N. Yamada and K. Kainuma. The Sago Palm Research Fund, Tokyo, 1986, p. 201.

4) A. Okamoto, T. Ozawa, H. Imagawa and Y. Arai, Nippon Nōgeikagaku Kaishi, 59, 1257 (1985).

5) H. Esterbauer, E. Schwarz and M. Hayn, Anal. Biochem., 77, 486 (1977).

6) K. Freudenberg and L. Purmann, Ann., 437, 274 (1924).

7) K. Tomiyama and M. A. Stahmann, Plant Physiol., 39, 483 (1964).

8) M. Bradford, Anal. Biochem., 72, 248 (1976).

9) B. J. Davis, Ann. N.Y. Acad. Sci., 121, 404 (1964).

10) J. L. Brewbaker, M. D. Upadhya, Y. Makinen and T. Macdonald, Physiol. Plant., 21, 930 (1968).

11) E. Harel and A. M. Mayer, Phytochemistry, 10, 17 (1971).

12) T. Takeo, Agric. Biol. Chem., 29, 558 (1965).

13) M. Kato, M. Omori, Y. Obata, R. Saijo, T. Takeo, T. Hasegawa and T. Suzuki, Nippon Nōgeikagaku Kaishi, 58, 999 (1984).

14) A. M. Mayer and E. Harel, Phytochemistry, 18, 193 (1979).

15) E. Harel, A. M. Mayer and E. Lehman, Phytochemistry, 12, 2640 (1973).

16) T. C. Wong, B. S. Luh and J. R. Whitaker, Plant Physiol., 48, 19 (1971).

17) N. J. Rivas and J. R. Whitaker, Plant Physiol., 52, 501 (1973).

18) T. Tohno, S. Fujita, H. Kawasaki and Z. Li, Nippon Nōgeikagaku Kaishi, 60, 705 (1986).

19) K. Söderhall, I. Carlberg and T. Eviksson, Plant Physiol., 78, 730 (1985).

20) E. Ichishima, H. Maeba, T. Amikura and H. Sakata, Biochim. Biophys. Acta, 786, 25 (1984).

21) D. A. Robb, L. W. Mapson and T. Swain, Phytochemistry, 4, 731 (1965). 
22) K. Balasingham and W. Ferdinand, Biochem. J., 118, 15 (1970).

23) N. Ben-Shalm, V. Kahn, M. Harel and A. M. Mayer,
Phytochemistry, 16, 1153 (1977).

24) E. O. Anosike and A. O. Ayaebene, Phytochemistry, 20, 2625 (1981). 